\title{
PENGARUH CINNAMALDEHYDE DARI KAYU MANIS (Cinnamomum burmanii) PADA PERIODONTAL DRESSING TERHADAP SEL FIBROBLAS PADA LUKA GINGIVA KELINCI
}

\author{
Made Lesya Vavata ${ }^{1}$, Ni Luh Putu Benita Lisda V. E. ${ }^{1}$, Syahrul Ramadhana ${ }^{1}$, Desak Nyoman Ari Susanti ${ }^{1}$ \\ ${ }^{1}$ Program Studi Sarjana Kedokteran Gigi dan Profesi Dokter Gigi, Fakultas Kedokteran, \\ Universitas Udayana, Denpasar \\ E-mail: echavavata@gmail.com
}

\begin{abstract}
Gingiva is the outermost structure of the periodontal tissue and play a role to protect the underlying tissue. Traumatic actions such as simple incisions, gingival flaps, and biopsy are the main causes of damage or injury to periodontal tissue. Application of a material to protect post-operative wounds is necessary. A common procedure related to this problem is periodontal dressing which serves to close the wound and accelerate the healing of gingival tissue. One type of plant that has a good ability to wound healing is cinnamon (Cinnamomum burmannii) with a compound called cinnamaldehyde. The use of this compound as a mixture in periodontal dressing has the potential to accelerate wound healing in the gingiva. This study aims to determine the effect of the addition of cinnamaldehyde from Cinnamomum burmannii on periodontal dressing on fibroblasts in healing gingival wounds in rabbits. The design of this study was an experimental laboratory study design with a post-test only with control group design. Experimental animals in the study were divided into 4 groups based on the presentation of the addition of cinnamon extract, namely $0 \%, 5 \%, 10 \%$, and $15 \%$. Each sample was again divided into small groups based on the day of decaputation consisting of days 3, 5, and 7. Statistical test results showed there were significant differences in the number of fibroblast cells between 3 subgroups (ANOVA, $p<0.05)$. Addition of cinnamon extract to periodontal dressing could increase the number of fibroblast cells after gingival injury.
\end{abstract}

Keywords: Gingival wound, cinnamaldehyde, fibroblast, periodontal dressing

\section{PENDAHULUAN}

Jaringan periodontal tersusun atas beberapa bagian yaitu gingiva, ligamen periodontal, sementum, dan tulang alveolar. Gingiva merupakan jaringan yang berada paling luar dan berfungsi untuk melindungi jaringan yang ada dibawahnya. ${ }^{1}$ Prosedur kedokteran gigi yang umumnya dapat menyebabkan luka pada daerah gingiva contohnya seperti insisi sederhana, gingival flap, dan biopsy. ${ }^{2}$

Penyembuhan luka merupakan salah satu proses biologis yang paling kompleks dalam kehidupan manusia. Sesaat ketika terjadinya luka, berbagai jalur biologis teraktivasi dan bersinkronisasi untuk memberi respon pada jaringan. ${ }^{3}$ Pada kondisi normal, suatu luka dapat sembuh secara klinis dalam beberapa minggu. Tahapan penyembuhan luka secara umum terbagi menjadi 4 fase yaitu koagulasi dan hemostatis, inflamasi, pembentukan jaringan baru, dan terakhir yaitu remodeling. Pada fase pembentukan jaringan baru atau proliferasi terjadi migrasi dari sel epitel, pembentukan pembuluh darah baru, dan differensiasi sel fibroblast. ${ }^{4-6}$ Sel fibroblas memegang peran yang krusial dalam mendukung proses penyembuhan luka, mulai dari pembentukan gumpalan fibrin, matriks ektraseluler baru, struktur kolagen yang membantu sel lain dalam proses penyembuhan luka serta berfungsi dalam melindungi luka saat terjadi kontraksi. ${ }^{7}$

Secara umum, proses penyembuhan luka untuk memperbaiki kerusakan pada suatu jaringan memiliki kesamaan proses untuk semua jenis jaringan. ${ }^{6}$ Namun, luka pada daerah rongga mulut memiliki masalah khusus seperti potensi infeksi bakteri yang tinggi dan kerusakan akibat proses mastikasi. ${ }^{8}$ Sejak tahun 1970an, berbagai prosedur telah dilakukan agar dapat mengembalikan kondisi jaringan periodontal yang hilang atau mengalami kerusakan. ${ }^{9}$ Pada sebagian besar kasus, area yang telah dilakukan prosedur bedah periodontal akan ditutup dengan periodontal dressing. Periodontal dressing ini mutlak diaplikasikan setelah prosedur bedah periodontal dan gingivektomi yang berfungsi untuk menutup luka dan mempercepat kesembuhan jaringan gingiva. ${ }^{10}$ Namun sebenarnya bahan ini tidak mengandung senyawa yang dapat mempercepat penyembuhan luka, melainkan hanya membantu penyembuhan karena luka terlindungi. ${ }^{8}$

Material periodontal dressing yang umum digunakan adalah berbahan dasar zinc oxide eugenol dan non-eugenol. Namun eugenol yang terkandung dalam periodontal dressing pada kebanyakan orang dapat memicu reaksi alergi, sehingga dibutuhkan jenis bahan lain yang lebih aman bagi tubuh. ${ }^{1}$ Saat ini penelitian tentang penyembuhan luka dengan memanfaatkan bahan alami sedang banyak dikembangkan dikarenakan jenis bahan ini dianggap lebih mudah untuk diterima oleh tubuh manusia, nontoksik, dapat digunakan dalam periode waktu yang lama dan tersedia dalam jumlah yang melimpah di alam. ${ }^{11}$ Salah satu jenis tanaman yang memiliki kemampuan yang baik dalam menyembuhkan luka yaitu kayu manis (Cinnamomum burmanii). Pada beberapa penelitian yang memanfaatkan kayu manis ini menunjukkan hasil bahwa tanaman ini dapat mempercepat proses penyembuhan luka kulit pada tikus. ${ }^{11}$ Sediaan minyak dari batang kayu manis terkandung senyawa 
cinnamaldehyde dengan kadar sebanyak 80-95\%. Senyawa ini dalam proses penyembuhan luka dapat merangsang proliferasi sel endotel, migrasi, proses pembentukan neovessel, serta pembentukan kolagen. ${ }^{12,13}$ Namun belum banyak penelitian yang memanfaatkan bahan ini pada luka di rongga mulut khususnya luka gingiva.

\section{BAHAN DAN METODE}

Metode yang digunakan dalam penelitian ini adalah metode eksperimental laboratoris dengan rancangan penelitian post test only control group design untuk mengetahui pengaruh penambahan cinnamaldehyde dari Cinnamomum burmanii pada periodontal dressing terhadap sel fibroblas pada penyembuhan luka gingiva di kelinci. Subyek penelitian ini terdiri dari 24 ekor kelinci jantan yang dibagi menjadi 4 kelompok sampel berdasarkan persentase penambahan cinnamaldehyde dari Cinnamomum burmanii yaitu kontrol (K) tanpa ditambahkan cinnamaldehyde dari Cinnamomum burmanii pada periodontal dressing, kelompok perlakuan 1 (KP1) ditambahkan 5\% cinnamaldehyde dari Cinnamomum burmanii pada periodontal dressing, kelompok perlakuan 2 (KP2) ditambahkan 10\% cinnamaldehyde dari Cinnamomum burmanii pada periodontal dressing, dan kelompok perlakuan 3 (KP3) ditambahkan 15\% cinnamaldehyde dari Cinnamomum burmanii pada periodontal dressing. Dengan masing-masing kelompok terdiri dari 6 ekor kelinci.

Tahap pembuatan ekstrak kayu manis dilakukan dengan cara maserasi bertingkat yaitu perendaman batang kayu manis kering sebanyak 500 gram pelarut DCM sebanyak $1000 \mathrm{ml}$ selama 2 x 24 jam dengan sekali-kali pengocokan. Kemudian maserat A dipisahkan dari ampas setelah 24 jam maserasi dan ditampung dalam bejana lain. Remaserasi dilakukan dengan memasukan pelarut sebanyak $800 \mathrm{ml}$ ke dalam bejana yang berisi residu (ampas), dan dilakukan pengocokan, lalu dibiarkan 24 jam. Maserat B dipisahkan setelah 24 jam, kemudian mencampur maserat A dan B dan dilakukan evaporasi dengan menggunakan alat rotary evaporator hingga diperoleh ekstrak minyak kayu manis. Selanjutnya dilakukan isolasi senyawa cinnamaldehyde dengan menggunakan kromatografi kolom. Dalam penelitian ini, teknik mengepak kolom yang digunakan adalah cara basah di mana silika dilarutkan dengan pelarut dichloromethane (DCM). Fraksi-fraksi yang keluar dari kolom ditampung ke dalam botol kaca $15 \mathrm{~mL}$ dan dimonitoring dengan kromatografi lapis tipis (KLT). Fraksi-fraksi yang memiliki spot dengan $\mathrm{Rf}$ yang sama atau mirip pada plat KLT dijadikan satu fraksi besar/utama.

Tahap manipulasi periodontal dressing CoePak dilakukan dengan mencampur pasta basis dan pasta akselerator sama panjang, yang diaduk sampai homogen. Setelah 2-3 menit pasta yang telah diaduk sudah dapat dibentuk.

Penambahan cinnamaldehyde dari Cinnamomum burmanii pada periodontal dressing dilakukan dengan perbandingan sebagai berikut:

\section{$\mathrm{K} \quad$ : 3 gram periodontal dressing}

$\mathrm{KP} 1$ :2,85 gram periodontal dressing dan ditambahkan 0,15 gram cinnamaldehyde dari Cinnamomum burmanii

KP2 : 2,7 gram periodontal dressing dan ditambahkan 0,3 gram cinnamaldehyde dari Cinnamomum burmanii

KP3 : 2,55 gram periodontal dressing dan ditambahkan 0,45 gram cinnamaldehyde dari Cinnamomum burmanii

Sebelum dilakukan perlakuan pada kelinci, terlebih dahulu kelinci diadaptasikan dengan lingkungan lab selama 7 hari. Kemudian kelinci diberi perlukaan pada gingiva rahang bawah dengan menggunakan punch biopsy berdiameter $4 \mathrm{~mm}$ yang sebelumnya kelinci telah anastesi dengan kombinasi ketamin dan xylazin. Kemudian luka dibalut dengan periodontal dressing yang telah ditambahkan cinnamaldehyde dari Cinnamomm burmanii untuk kelompok perlakuan dan tanpa penambahan cinnamaldehyde dari Cinnamomm burmanii untuk kelompok kontrol. Setiap kelompok perlakuan dibagi menjadi empat sub kelompok sesuai dengan hari dekaputasi, yaitu pada hari ke-3, 5, dan 7. Kemudian dilakukan proses pembuatan preparat jaringan dengan tahapan yaitu fiksasi, trimming, dehydration, clearing, impregansi, embedding, dan cutting. Selanjutnya dilakukan pewarnaan preparat jaringan menggunakan Hematoksilin-Eosin (HE) dan sel fibroblas diamati dengan mikroskop dengan pembesaran 400x pada 5 lapang pandang. Seluruh tindakan yang dilaksanakan pada penelitian ini telah disetujui oleh Komisi Etik Penelitian (KEP) Fakultas Kedokteran Universitas Udayana (No:1742/UN14.2.2.VII.14/LP/ 2019 ).

\section{HASIL DAN PEMBAHASAN}

Pengamatan pada 24 kelinci yang terbagi menjadi 4 kelompok dengan menghitung jumlah sel fibroblas pada preparat histologis menggunakan perbesaran 400x. Data hasil penghitungan jumlah sel fibroblas yang telah diperoleh kemudian diolah menggunakan uji Two-way ANOVA. Sebelum melakukan uji Two-way ANOVA dilakukan uji normalitas terlebih dahulu dengan penghitungan uji Saphiro-Wilk dan uji tersebut menunjukkan signifikasi sebesar 0,952 ( $p>0,05)$ yang diperlihatkan pada Tabel 1 . Hal ini berarti data penelitian berdistribusi normal.

Selanjutnya dilakukan uji homogenitas varians terhadap data jumlah sel fibroblas dilakukan untuk mengetahui homogenitas data. Hasil uji homogenitas menunjukkan signifikasi sebesar 0,743 (p>0,05) yang diperlihatkan pada Tabel 2, hal ini berarti data penelitian bersifat homogen

Setelah dilakukan uji Two-way ANOVA, hasilnya menunjukkan terdapat bahwa rata-rata jumlah sel fibroblas pada kelompok perlakuan lebih banyak dibandingkan kelompok kontrol. Jumlah sel fibroblas paling banyak terdapat pada kelompok perlakuan yang diberikan periodontal dressing yang ditambahkan cinnamaldehyde $15 \%$ (KP3) dibandingkan semua kelompok perlakuan pada hari ke-3, 5, dan 7. Hasil secara lebih jelas dapat dilihat pada Tabel 3 . 
Tabel 1. Rata-rata jumlah sel fibroblas pada kelompok perlakuan

\begin{tabular}{|c|c|c|c|}
\hline \multirow{2}{*}{ Kelompok } & \multicolumn{3}{|c|}{ Hari Dekaputasi $(\mathrm{X} \pm \mathrm{SD})$} \\
\hline & 3 & 5 & 7 \\
\hline $\mathrm{K}$ & $21 \pm 2,828$ & $16.5 \pm 2,121$ & $14 \pm 4,243$ \\
\hline KP1 & $22.5 \pm 2,121$ & $20.5 \pm 3,536$ & $17 \pm 2,828$ \\
\hline KP2 & $26.5 \pm 2,121$ & $23 \pm 4,243$ & $21 \pm 4,243$ \\
\hline KP3 & $32.5 \pm 4,950$ & $28.5 \pm 3,536$ & $23 \pm 2,828$ \\
\hline $\begin{array}{l}\text { Ket: }(\mathrm{X} \pm \mathrm{SD}): \\
\text { K: Kelon } \\
\text { Coe-Pak } \\
\text { KP1: Ke } \\
\text { Coe-Pak } \\
\text { KP2: Ke } \\
\text { Coe-Pak } \\
\text { KP3: Ke } \\
\text { Coe-Pak }\end{array}$ & $\begin{array}{l}\text { ta-rata } \pm \text { stand } \\
\text { ok kontrol den } \\
\text { mpok perlakua } \\
\text { an } 5 \% \text { cinname } \\
\text { mpok perlakua } \\
\text { an } 10 \% \text { cinnan } \\
\text { mpok perlakua } \\
\text { an } 15 \% \text { cinnan }\end{array}$ & $\begin{array}{l}\text { deviasi } \\
\text { n periodontal } \\
\text { lengan period } \\
\text { ehyde, } \\
\text { lengan period } \\
\text { dehyde, } \\
\text { lengan period } \\
\text { dehyde }\end{array}$ & $\begin{array}{l}\text { al dressing } \\
\text { al dressing } \\
\text { al dressing }\end{array}$ \\
\hline
\end{tabular}

Tabel 2. Rangkuman hasil uji Two-way ANOVA jumlah sel fibroblas

\begin{tabular}{ccc}
\hline Source & F & Signifikansi \\
\hline Hari & 8,046 & $0,006^{*}$ \\
Kelompok & 11,149 & $0,001^{*}$ \\
Kelompok-Hari & 0,202 & $0,97^{*}$ \\
\hline
\end{tabular}

Ket: “_“ menunjukkan interaksi, F : nilai F hitung, * : berbeda bermakna $(\mathrm{p}<0,05)$

Hasil Two-way ANOVA pada Tabel 2 menunjukkan perbedaan bermakna rata-rata jumlah sel fibroblas pada masing-masing hari pengamatan, kelompok perlakuan dan interaksi antara hari pengamatan dan kelompok perlakuan $(p<0,05)$. Hal ini berarti bahwa hari pengamatan dan kelompok perlakuan berpengaruh signifikan terhadap jumlah sel fibroblas, sedangkan interaksi antara hari pengamatan dan kelompok perlakuan tidak berpengaruh signifikan $(\mathrm{p}>0,05)$. Oleh karena itu perlu dilakukan uji LSD (Least Square Difference) yang merupakan uji lanjutan untuk mengetahui kombinasi mana yang berbeda secara bermakna. Hasil uji LSD dapat dilihat pada Tabel 3.

Tabel 3. Hasil uji LSD

\begin{tabular}{ccccc}
\hline $\begin{array}{c}\text { Perbedaan Antar } \\
\text { Kelompok }\end{array}$ & $\begin{array}{c}\text { Beda } \\
\text { Rerata }\end{array}$ & $\begin{array}{c}\text { Std. } \\
\text { Error }\end{array}$ & $\begin{array}{c}\text { Signifikansi } \\
(\mathrm{P})\end{array}$ \\
\hline K & KP1 & $-2,83$ & 1,979 & 0,178 \\
& KP2 & $-6,33$ & 1,979 & $0,008^{*}$ \\
& KP3 & $-10,83$ & 1,979 & $0,000^{*}$ \\
KP1 & K & 2,83 & 1,979 & 0,178 \\
& KP2 & $-3,50$ & 1,979 & 0,102 \\
& KP3 & $-8,00$ & 1,979 & $0,002^{*}$ \\
KP2 & K & 6,33 & 1,979 & $0,008^{*}$ \\
& KP1 & 3,50 & 1,979 & 0,102 \\
& KP3 & $-4,50$ & 1,979 & $0,042^{*}$ \\
KP3 & K & 10,83 & 1,979 & $0,000^{*}$ \\
& KP1 & 8,00 & 1,979 & $0,002^{*}$ \\
& KP2 & 4,50 & 1,979 & $0,042^{*}$ \\
\hline Keterangan
\end{tabular}

Keterangan : * Signifikan $(\mathrm{p}<0,05)$
Hasil uji LSD menunjukkan perbedaan bermakna $(\mathrm{p}<0,05)$ rerata jumlah sel fibroblas antara KP3 dengan semua kelompok lain serta juga terdapat perbedaan bermakna antara kelompok kontrol dan KP2; sedangkan antara kelompok kontrol dan KP1 serta antara KP2 dan KP1 menunjukkan perbedaan yang tidak bermakna (p>0,05).

Hasil penelitian ini membuktikan jumlah sel fibroblas yang lebih banyak pada kelompok perlakuan dibandingkan dengan kelompok kontrol. Hal ini membuktikan bahwa penambahan cinnamaldehyde dari ekstrak kayu manis pada periodontal dressing dapat mempercepat proses penyembuhan luka gingiva, melalui peran perantara makrofag yang merangsang faktor pertumbuhan sehingga meningkatkan proliferasi sel fibroblas. Makrofag akan memfagosit dan membunuh bakteri, kemudian melepaskan dan menginduksi aktifnya sitokin berupa IL-1 (interleukin 1), TNF (tumor necrosis factor), serta faktor pertumbuhan seperti Platelet Derived Growth Factor (PDGF), Transforming Growth Factor- $\beta$ (TGF- $\beta$ ), Fibroblast Growth Factor (FGF), dan Epidermal Growth Factor (EGF). Produk sitokin tersebut akan menstimulasi migrasi dan proliferasi sel fibroblas, serta produksi dan modulasi matriks ekstraselular. ${ }^{14}$

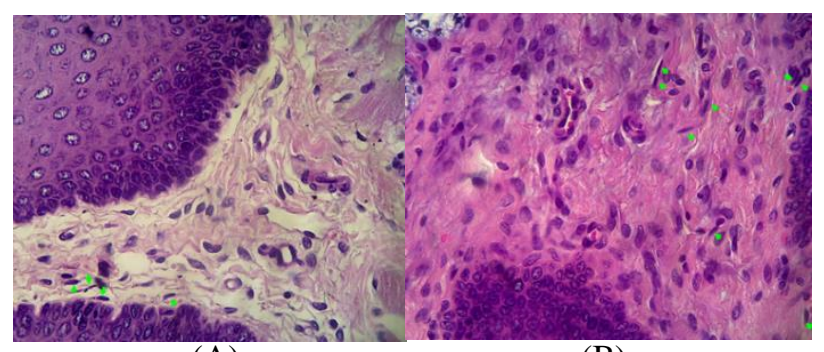

(A)

(B)

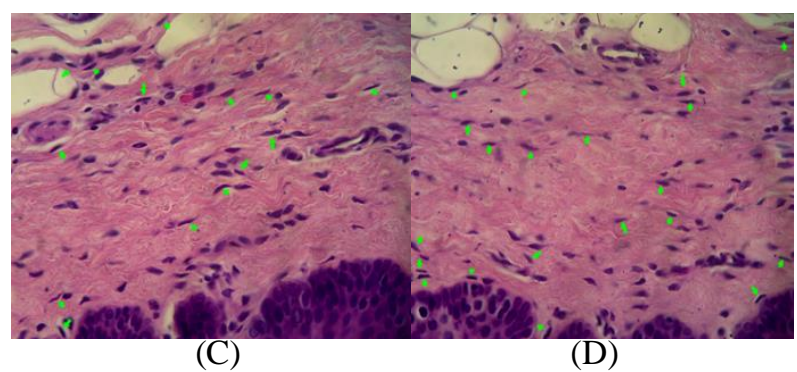

Gambar 1. Gambaran mikroskopik sel fibroblas (tanda panah hijau). (A) Kelompok kontrol (K), (B) KP1, (C) $\mathrm{KP}$ 2, dan (D) KP3 pada hari ke-3 dengan pengecatan HE pembesaran $400 x$

Pada hari ke-3 terlihat bahwa rerata jumlah sel fibroblas pada semua kelompok perlakuan lebih banyak dibandingkan dengan kelompok kontrol (Gambar 1). Hal tersebut dikarenakan adanya kandungan cinnamaldehyde yang merupakan senyawa antioksidan potensial dalam kulit kayu manis serta yang memiliki kemampuan untuk menarik radikal bebas yang berhubungan dengan fase inflamasi. Penghambatan ini akan menyebabkan penurunan kandungan asam arakidonat pada jaringan membran fosfolipid sel yang mengakibatkan terhambatnya pelepasan sejumlah mediator inflamasi seperti prostaglandin, leukotrin, dan 
tromboksan, sehingga akan menurunkan respon inflamasi. $^{11}$

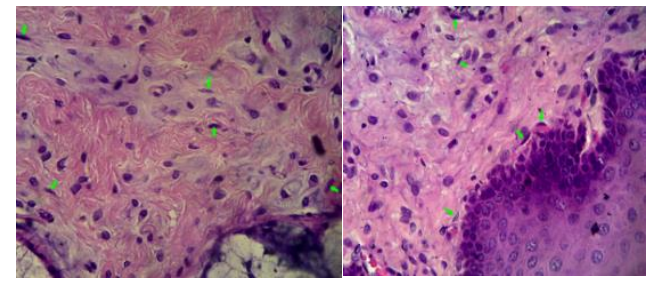

(A) (B)

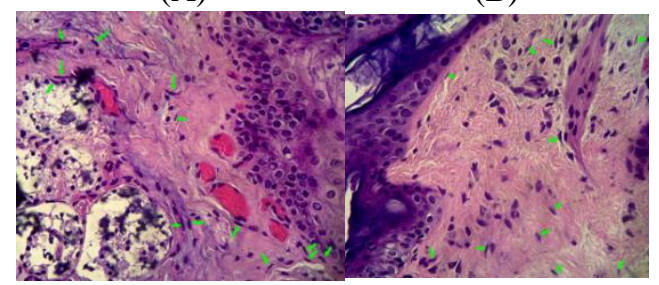

(C)

(D)

Gambar 2. Gambaran mikroskopik sel fibroblas (tanda panah hijau). (A) Kelompok kontrol (K), (B) KP1, (C) $\mathrm{KP} 2$, dan (D) KP3 pada hari ke-5 dengan pengecatan HE pembesaran 400x.

Jumlah sel fibroblas pada hari ke-5 mengalami penurunan dibandingkan dengan kelompok pengamatan pada hari ke-3, karena pada hari ke-5 terjadi penurunan proliferasi sel fibroblas untuk pembentukan serabut kolagen. ${ }^{15}$ Sintesis kolagen oleh sel fibroblas dimulai relatif awal pada proses penyembuhan hari ke 3-5 dan berlanjut terus sampai beberapa minggu tergantung ukuran luka. Pada hari ke-5 tampak bahwa rata-rata jumlah sel fibroblas pada kelompok perlakuan lebih banyak dibandingkan dengan kelompok kontrol. Hal ini disebabkan adanya aktivitas antibakterial dari senyawa cinnamaldehyde melalui mekanisme denaturasi protein bakteri, membentuk komplek dengan dinding sel bakteri dan merusak membran sel bakteri. Kemampuan tersebut sangat penting karena kematian bakteri akan mengakibatkan berkurangnya proses fagositosis bakteri oleh sel leukosit PMN. Hal tersebut mengakibatkan fase inflamasi berlangsung singkat, sehingga fase proliferasi juga berlangsung lebih awal. ${ }^{11,16}$

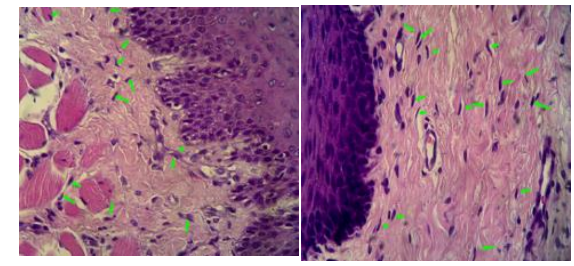

(A)

(B)

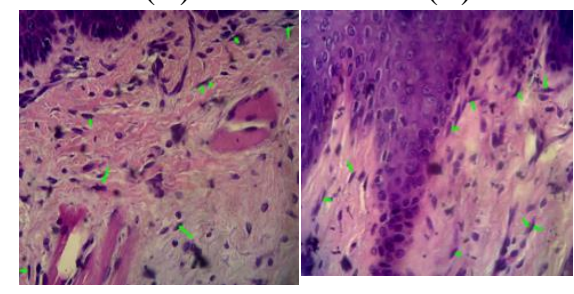

(C)

(D)

Gambar 3. Gambaran mikroskopik sel fibroblas (tanda panah hijau). (A) Kelompok kontrol (K), (B) KP1, (C)
KP2, dan (D) KP3 pada hari ke-7 dengan pengecatan HE pembesaran 400x.

Pada hari ke-7 tampak bahwa jumlah sel fibroblas mengalami penurunan dibandingkan dengan jumlah sel fibroblas hari ke-5. Hal tersebut dikarenakan pada penelitian ini menggunakan hewan coba kelinci yang waktu penyembuhannya lebih cepat daripada manusia, sehingga proses sintesis kolagen oleh sel fibroblas dimulai relatif awal pada minggu pertama. ${ }^{17}$ Sesuai dengan pernyataan bahwa sintesis kolagen oleh sel fibroblas mencapai puncaknya pada hari ke-5 sampai ke-7. Sel fibroblas sudah mulai meninggalkan jaringan granulasi, warna kemerahan dari jaringan sudah berkurang, karena pembuluh sudah berkurang. Serat fibrin dan kolagen sudah bertambah banyak untuk memperkuat jaringan parut. ${ }^{18}$

\section{SIMPULAN}

Berdasarkan hasil penelitian yang telah dilakukan dapat disimpulkan bahwa penambahan cinnamaldehyde dari Cinnamomum burmanii pada periodontal dressing berpotensi dalam meningkatkan jumlah sel fibroblas pada luka gingiva kelinci dengan presentase yang paling efektif yaitu pada KP3 sebesar $15 \%$. Peningkatan jumlah fibroblast pada KP3 terbukti signifikan dengan nilai $\mathrm{p}<0,05$ dibandingkan dengan semua kelompok lainnya dan terjadi diketiga hari pengamatan.

\section{UCAPAN TERIMA KASIH}

Segenap tim peneliti mengucapkan terima kasih kepada semua pihak yang telah membantu dan memberikan kontribusi sehingga penelitian ini dapat terselesaikan.

\section{DAFTAR PUSTAKA}

1. Newman MG, Takei HH, Carranza FA. Carranza's Clinical Periodontology, Volume 1. Carranza's Clinical Periodontology. 2002.

2. American Academy of Periodontology. Glossary of Periodontal Term. J Periodontol. 2001;

3. Li J, Chen J, Kirsner R. Pathophysiology of acute wound healing. Clin Dermatol. 2007;

4. Reinke JM, Sorg H. Wound repair and regeneration. Eur Surg Res. 2012;49(1):35-43.

5. Clark R. wound repair: Overview and general considirations. In: The Molecular and Cellular Biology of Wound Repair. 2013.

6. Velnar T, Bailey T, Smrkolj V. The wound healing process: An overview of the cellular and molecular mechanisms. Journal of International Medical Research. 2009.

7. P. B. Wound healing and the role of fibroblasts. J Wound Care [Internet]. 2013;22(8):407-12. Available from: http://www.magonlinelibrary.com/doi/10.12968/jow c. 2013.22.8.407 
8. Habiboallah G, Mahdi Z, Majid Z, Nasroallah S, Taghavi AM, Forouzanfar A, et al. Enhancement of Gingival Wound Healing by Local Application of Silver Nanoparticles Periodontal Dressing Following Surgery: A Histological Assessment in Animal Model. Mod Res Inflamm. 2014;

9. Polimeni G, Xiropaidis A V., Wikesjö UME. Biology and principles of periodontal wound healing/regeneration. Periodontology 2000. 2006.

10. Kale DT, Dani DN, Patange DT. Periodontal Dressing. IOSR J Dent Med Sci. 2014;13(3):94-8.

11. Farahpour MR, Amniattalab A, Hajizadeh $H$. Evaluation of the wound healing activity of Cinnamomum zeylanicum extract on experimentally induced wounds in rats. 2012;11(84):15068-71.

12. Yuan X, Han L, Fu P, Zeng H, Lv C, Chang W, et al. Cinnamaldehyde accelerates wound healing by promoting angiogenesis via up-regulation of PI3K and MAPK signaling pathways. Lab Investig. 2018;98(6):783-93.
13. Takasao N, Tsuji-Naito K, Ishikura S, Tamura A, Akagawa M. Cinnamon extract promotes type i collagen biosynthesis via activation of IGF-I signaling in human dermal fibroblasts. J Agric Food Chem. 2012;

14. Gallin JI, Goldstein IM, Snyderman. R. Inflammation: Basic Principles and Clinical Correlates. 1st ed. New YOrk: Raven Press; 1988.

15. Eming SA, Martin P, Tomic-Canic M. Wound repair and regeneration: Mechanisms, signaling, and translation. Science Translational Medicine. 2014.

16. Zhang Y-B, Liu X-Y, Jiang P-P, Li W-D, Wang YF. Mechanism and antibacterial activity of cinnamaldehyde against Escherichia coli and Staphylococcus aureus. Mod Food Sci Technol. 2015;31:31-5 and 11.

17. Eurell JA, Brian L. Frappier DVM. Dellmann's Textbook of Veterinary Histology. Wiley; 2013.

18. Singh S, Young A, McNaught CE. The physiology of wound healing. Surgery (United Kingdom). 2017. 